\title{
SAUDAÇÃO AOS CONGRESSISTAS - FEITA PELA PRESIDENTE DO I CONGRESSO REGIONAL SUL-AMERICANO DO CICIAMS*
}

Constitui para nós uma grande honra compartilhar da presidência deste duplo congresso, na qualidade de Presidente Regional da Seção Sul-Amerícana do Comitê Internacional Católico de Enfermeiras e Assistentes Mé di co-Sociais (CICIAMS).

Entidade Internacional Católica, o CICIAMS tem o propósito de auxiliar na criaçāo e organizaçāo de associaçōes nacionais católicas e coordenar suas atividades, visando a torná-las o próprio reflexo do pensamento cristão na enfermagem. Objetiva também oferecer aos enfermeiros católicos apoio e assistência no processo de contínuo aperfeiçoamento pessoal e religioso no desenvolvimento das virtudes cristās indispensáveis ao bom desempenho de suas atividades profissionais. Empenha-se em torná-las exemplo vivo do Cristo junto aos enfermos e no ambiente de trabalho e com isto melhorar a assistência integral aos doentes, com ênfase no aspecto psicológico e religioso.

No Brasil não há uma associação católica de enfermeiros. Os objetivos da Associação Brasileira de Enfermagem, a unidade de propósitos e a formação cristã e ao mesmo tempo ecumênica de seus membros, tem suprido até agora a necessidade da formaçāo de grupos confissionais na profissão.

Esta é a segunda vez que, sob os auspícios de $A B e n$, realiza-se um Congresso do CICIAMS nesta cidade do Rio

\footnotetext{
- dra. Amália Corréa de Carvalho
}

de Janeiro, com a participação de colegas dos países latino-americanos. Temos a satisfaçāo de contar com delegados do Equador, Peru, Chile, Colombia, Paraguai e Bolívia.

Em 1961, o II Congresso Latino-Americano dessa Entidade católica teve como lema "o sentido cristāo de servir". O I Congresso Regional Sul-Americano que ora se instala conjuntamente com 0 XXVIII Congresso Brasileiro de Enfermagem, debaterá assunto de igual relevância para os dias atuais - "a formação filosófica e religiosa da enfermeira".

Teremos novamente 0 grande prazer de confraternizar e conviver, ainda que por prucos dias, com nossas colegas dos países da América do Sul. Temos certeza de que sua permanência entre nós será motivo de alegria fraternal para todos e de enriquecimento cultural e profissional para os enfermeiros brasileiros, que carinhosamente as hospedam.

Esperamos que o espírito cristão que nos une e aproxima presida a todas as atividades desse duplo Congresso que se inicia na data do cinquentenário da Associação Brasileira de Enfermagem. Que Deus abençoe nossos trabalhos e dirija nossos passos para o caminho do aperfeiçoamento profissional, nos seus aspectos técnico-científico, moral, espiritual e ético.

A todos os congressistas, visitantes ou brasileiros, votos de boas-vindas e os agradecimentos pela presença nesta sessão solene. 